\title{
Hydrochemical evaluation of Lower Niger Drainage Area, southeastern Nigeria
}

\author{
C. M. Okolo' - B. E. B. Akudinobi ${ }^{1} \cdot$ I. I. Obiadi ${ }^{1}$ E. N. Onuigbo' ${ }^{1}$ P. N. Obasi ${ }^{2}$
}

Received: 24 October 2017 / Accepted: 11 October 2018 / Published online: 17 October 2018

(c) The Author(s) 2018

\begin{abstract}
Hydrochemical evaluation of parts of Lower Niger Drainage Area was studied. The distribution and concentration of the major ions were assessed. Atomic absorption spectroscopic and spectrophotometric methods were employed in the analyses of chemical species in water, and Piper, Durov and Schoeller diagrams were used in the processing and interpretation of the results. The results of the hydrochemical analysis show the generalized ionic sequence in the study area as $\mathrm{K}^{+}>\mathrm{Ca}^{2+}>\mathrm{Na}^{+}>\mathrm{Mg}^{2+}$ and $\mathrm{Mg}^{2+}>\mathrm{Ca}^{2+}>\mathrm{Na}^{+}>\mathrm{K}^{+}$in wet season and $\mathrm{Cl}^{-}>\mathrm{SO}_{4}{ }^{2-}>\mathrm{HCO}_{3}{ }^{-}>\mathrm{NO}_{3}{ }^{-}$in dry season, respectively. Two major water types predominate: $\mathrm{Ca}-\mathrm{Mg}-\mathrm{HCO}_{3}(17.1 \%)$ and $\mathrm{Na}-\mathrm{K}-\mathrm{Cl}-\mathrm{SO}_{4}(82.9 \%)$. The dominant hydrochemical facies observed include $\mathrm{Cl}-\mathrm{SO}_{4}$ and $\mathrm{Ca}-\mathrm{Mg}-\mathrm{HCO}_{3}$, while $\mathrm{Cl}-\mathrm{HCO}_{3}-\mathrm{NO}_{3}$ occurs to a lesser degree. The various facies present depict mixing of water from different sources, weathering of carbonates and silicates and ion exchange processes leading to increased concentration of calcium and magnesium ions in relation to sodium and potassium ions. The presence of calcium, chloride and sulphate species indicates the existence of inverse ion exchange. The water in the study area shows variation in the concentration of ionic species with seasons, while the water type is not season dependent.
\end{abstract}

Keywords Water quality $\cdot$ Water type $\cdot$ Hydrochemical analysis $\cdot$ Nigeria

\section{Introduction}

The Lower Niger Drainage Area is endowed with many surface water bodies including Rivers Anambra, Idemili, Nkisi and Nwangene with other minor streams and groundwater. These surface water and groundwater sources serve variable useful socio-economic purposes to urban, semi-urban and rural population along their courses.

Hydrochemical processes of groundwater vary spatially and temporally, depending on geology and chemical characterization of the aquifer (Lakshamanan et al. 2003; Batayneh et al. 2014; Ravnborg 2016). Natural geochemical processes including dissolution of minerals, ion exchange, precipitation, oxidation and reduction are the predominant factors that contribute to fluvial hydrochemistry, while anthropogenic activities (industrial and agricultural) impose

\section{M. Okolo}

chymeokolo@yahoo.com

1 Department of Geological Sciences, Nnamdi Azikiwe University, Awka, Anambra State, Nigeria

2 Department of Geology, Ebonyi State University, Abakaliki, Ebonyi State, Nigeria supplementary effects (Batayneh et al. 2014; Aghazadel et al. 2016; Barzegar 2016). These chemical processes alter the ionic constituents and may change the $\mathrm{pH}$ of water (Elango et al. 2003; Jalali 2008).

A comprehensive review of groundwater chemistry of Nigeria (Edet et al. 2011) shows the distribution of ionic species in the sedimentary area as $\mathrm{Na}^{+}>\mathrm{Ca}^{2+}>\mathrm{K}^{+}>\mathrm{Mg}^{2+}$, while Batayneh et al. (2014) reported the ionic abundance in a coastal aquifer as $\mathrm{Ca}^{2+}>\mathrm{Na}^{+}>\mathrm{Mg}^{2+}>\mathrm{K}^{+}$and $\mathrm{Cl}^{-}>\mathrm{SO}_{4}{ }^{2-}>\mathrm{HCO}_{3}{ }^{-}>\mathrm{NO}_{3}{ }^{-}$. $\mathrm{Na}-\mathrm{SO}_{4}-\mathrm{Cl}$ facies represent fossil water (discharge areas), and $\mathrm{Ca}-\mathrm{Mg}-\mathrm{SO}_{4}-\mathrm{Cl}$ dominates in recharge areas (Aghazadel et al. 2016). The study area is a coastal; the present study will assess variations or conformity to the order. The presence of a number of hydrochemical facies in an area suggests mixing of water from different sources (Bonoto 2006). Similarly, Nwankwoala (2013) classified water in the eastern part of Warri as acidic with elevated chloride and the water type as $\mathrm{Ca}-\mathrm{Mg}-\mathrm{Cl}-\mathrm{SO}_{4}$ and $\mathrm{Na}-\mathrm{K}-\mathrm{Cl}-\mathrm{SO}_{4}$. Nwankwoala and Udom (2011) and Ige and Karade (2014) reported the order of abundance of hydrochemical species in groundwater in Port Harcourt as $\mathrm{Mg}^{2+}>\mathrm{Ca}^{2+}>\mathrm{Na}^{+}>\mathrm{K}^{+}$and 
$\mathrm{Cl}^{-}>\mathrm{SO}_{4}{ }^{2-}>\mathrm{HCO}_{3}{ }^{-}>\mathrm{NO}_{3}{ }^{-}$and the water types as $\mathrm{Ca}-\mathrm{Mg}-\mathrm{Cl}-\mathrm{SO}_{4}$ and $\mathrm{Na}-\mathrm{K}-\mathrm{Cl}-\mathrm{SO}_{4}$.

The knowledge of processes that control groundwater chemical evolution could lead to improved understanding of hydrochemical characterization of an aquifer and will contribute to groundwater resources management (Wurbs 2017). Therefore, the present study will assess the predominant hydrochemical processes such as rock-water interaction, ion exchange processes and dissolution, and effect of seasonal variation on water type, chemical species in water, the ionic sequence and determine recharge and discharge areas in parts of Lower Niger Drainage Area and their control on the hydrochemistry of water sources.

\section{Location of the study area}

The Lower Niger Drainage Area lies within latitudes $6^{\circ} 03^{\prime}$ and $6^{\circ} 21^{\prime} \mathrm{N}$ and longitudes $6^{\circ} 46^{\prime}$ and $6^{\circ} 55^{\prime} \mathrm{E}$ (Fig. 1). The major towns include Onitsha, Odekpe, Atani (drained by the River Niger), Obosi, Nkpor, Ojoto, Oba (drained by River Idemili), Nsugbe, Aguleri, Umuleri, Otuocha, Anam (drained by River Anambra) and Ogidi, Ogbunike and Nkwelle-Ezunaka (drained by River Nkisi). The total areal extent is about $643 \mathrm{~km}^{2}$ and has a population of about $1,276,396$. It is underlain by the alluvium plain, along the coast of Anambra and Idemili Rivers, the Ogwashi-Asaba

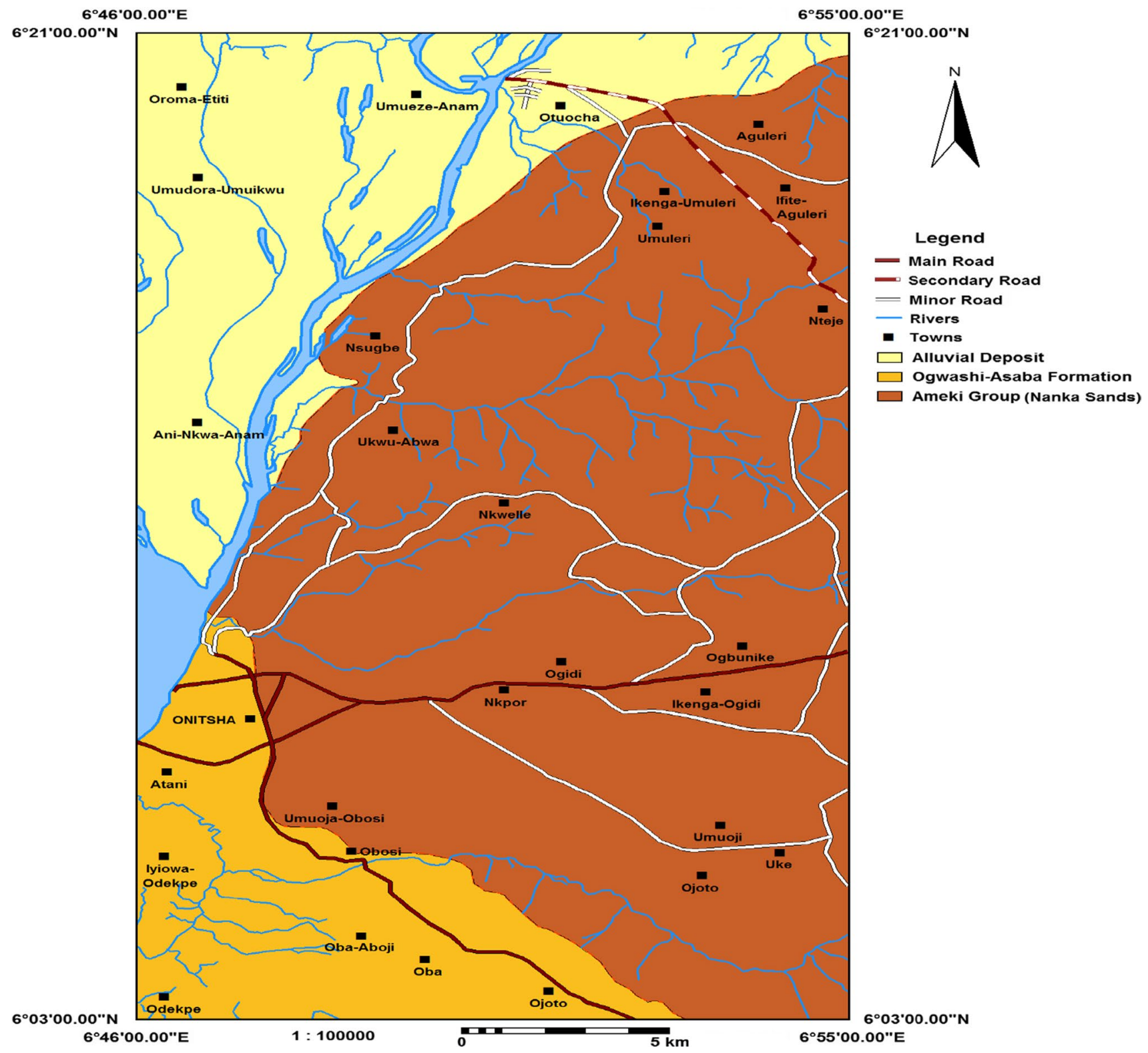

Fig. 1 Geologic map of the study area 


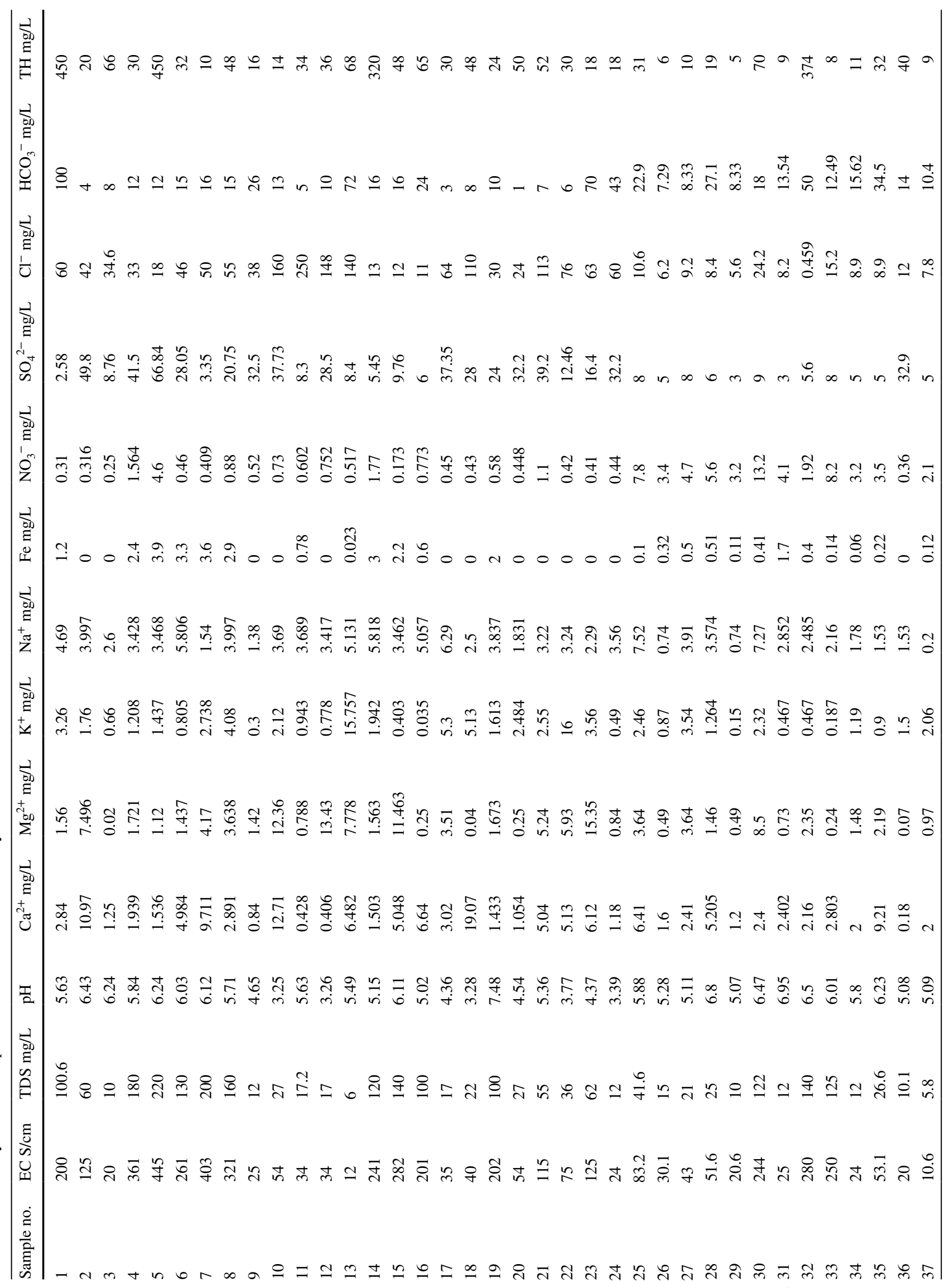




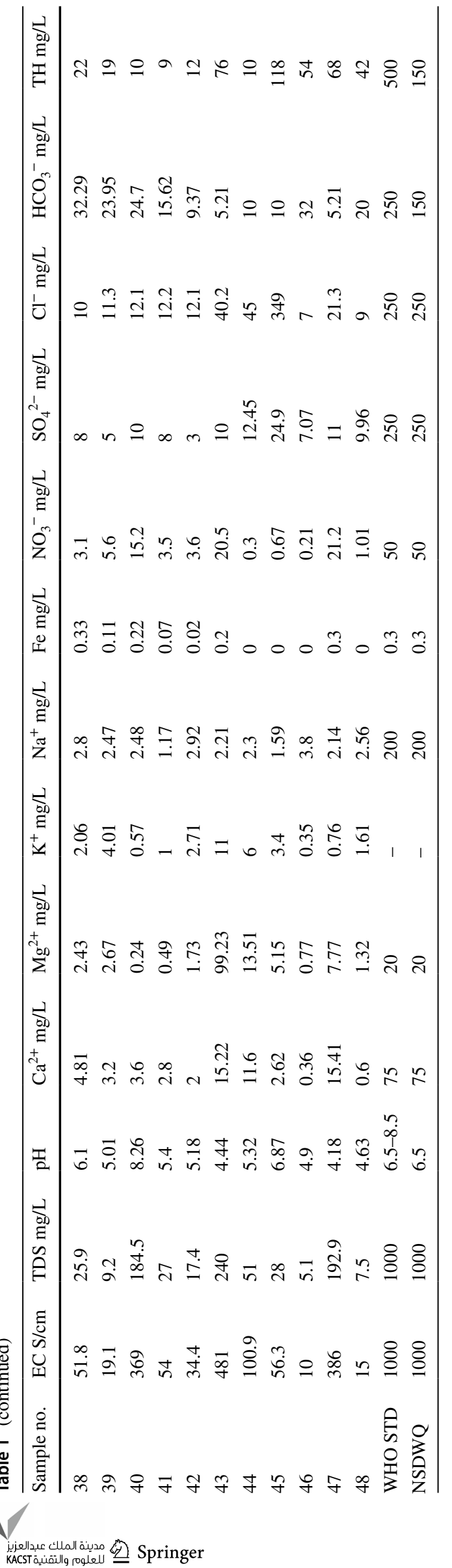

Formation in the south western part and the Ameki Group (Nanka Sand) in the remaining parts.

\section{Materials and methods}

Several methods were employed in carrying out this research, and they can be summarized under data collection, laboratory analysis and data processing. Systematic fieldwork involved surface geological mapping, identification of surface water and groundwater sources, and collection of samples was carried out. The study area was systematically mapped to identify the various rock types and their distribution.

Water survey was carried out for surface water and groundwater sources in wet (August-September) and dry (January-February) seasons of 2016. Forty-eight doublet samples were collected in each season. The samples were collected with a one litre plastic can and labelled appropriately. The surface water samples were collected from major rivers at different points, while groundwater samples were randomly collected from pre-existing water boreholes. The plastic cans were washed with detergents, and at sampling points, they were rinsed three times with the raw samples prior to collection. One set of samples was used for the anion analysis, while the other set was used for cation analysis. The samples for cation analysis were filtered at the point of collection, using Whatman filter paper $(0.45 \mu \mathrm{mm}$ pore size $)$. The filtrate was acidified with few drops of dilute nitric acid.

The chemical analysis was carried out at 7UP Bottling Company, 9th Mile, Enugu State, and Spring Board Research Laboratory, Awka. The cations were analyzed using Varian AA 240 Atomic Absorption Spectrophotometer (AAS). Hundred millilitres of thoroughly (homogeneously) mixed sample was transferred into a $250-\mathrm{mL}$ volumetric glass beaker, $5 \mathrm{~mL}$ of concentrated nitric acid was added, and the entire volume was heated to boil till it was reduced to $20 \mathrm{~mL}$; concentrated nitric acid was added in increments of $5 \mathrm{~mL}$ till all the residue was completely dissolved. The mixture was cooled, transferred into another beaker and made up to $100 \mathrm{~mL}$ using metal-free distiled water. The sample was aspirated, into the oxidizing air-acetylene flame. When the aqueous sample was aspirated, the sensitivity for $1 \%$ absorption was observed. This procedure was used in the analysis of the metals using their individual lamps. The anions were analyzed using UV-visible spectrophotometer (PD 303 UV Spectrophotometer) according to manufacturer's manual and the specification of APHA (1998). 


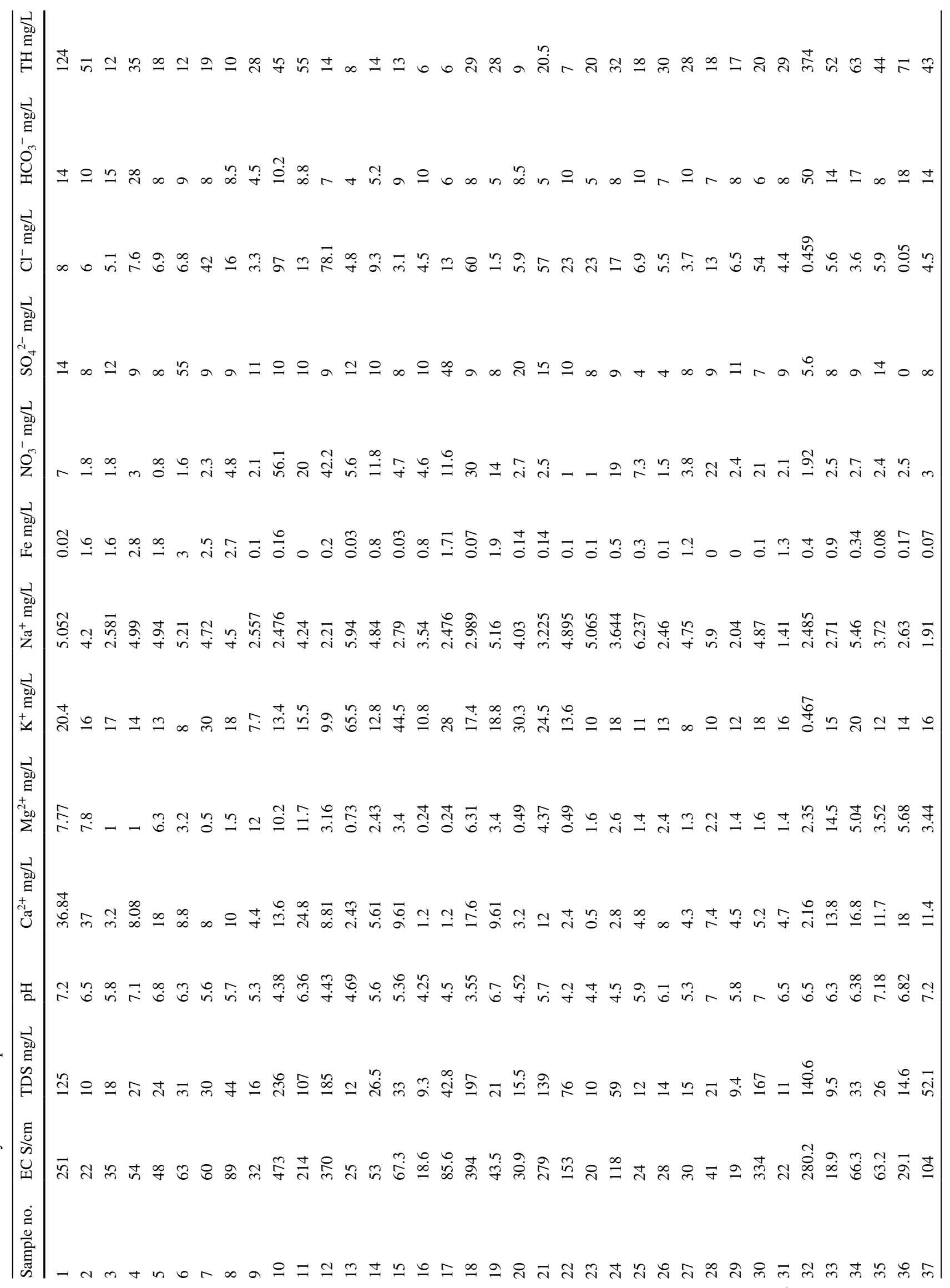




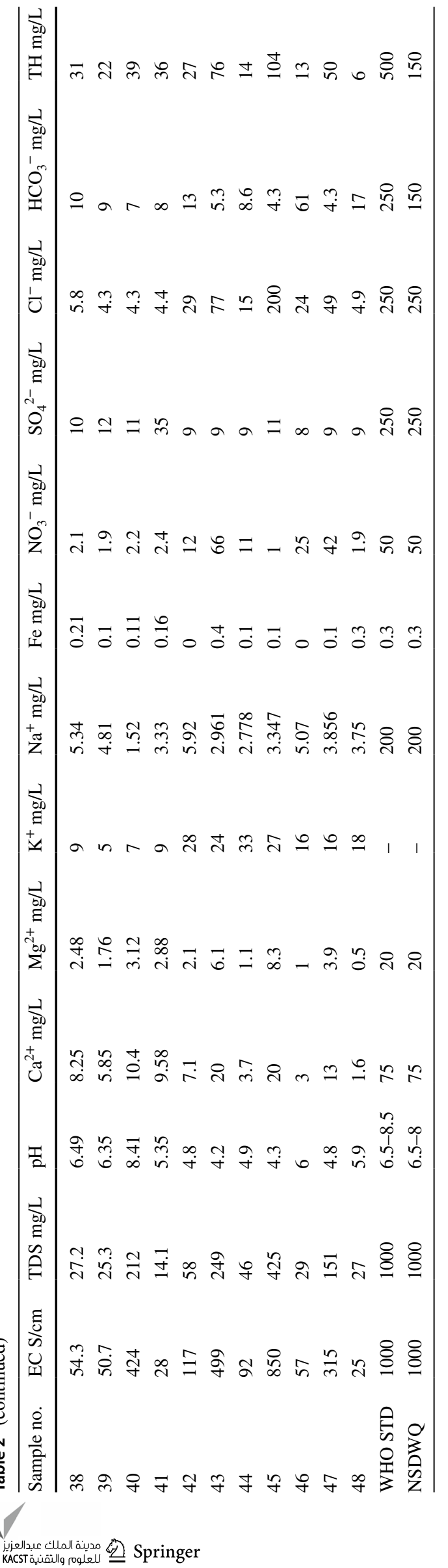

Results and discussion

\section{Distribution of hydrochemical parameters in water sources}

The results of the chemical analyses were compared with World Health Organization (WHO 2008) and Nigerian Drinking Water Quality (NSDWQ 2007) guidelines (Tables 1,2). The ionic species in water varied from zone to zone and in surface water sources with season. The total dissolved solids (TDS), electrical conductivity (EC) and total hardness $(\mathrm{TH})$ were within the permissible limits of the guidelines. $\mathrm{pH}$ of water sources ranged from 3.55 to 8.41 and 3.25 to 7.48 , with mean values of 5.62 and 5.48 for wet and dry seasons, respectively. The $\mathrm{pH}$ ranged from acidic to alkaline and an increase in acidity towards Onitsha and Obosi zones was characterized by increased industrialization and urbanization, implying anthropogenic activities as major contributor.

The variation in the order of major ions from what obtains in a sedimentary environment (Edet et al. 2011) can be attributed to variation in the mineralogical and chemical constitution of the rocks, climatic conditions, mobility of ions and geochemical processes such as ion exchange and inverse ion exchange. The order of the distribution of the major ions varies from zone to zone and in surface water (Table 3). However, the general order of distribution of cations in the study area was $\mathrm{K}^{+}>\mathrm{Ca}^{2+}>\mathrm{Na}^{+}>\mathrm{Mg}^{2+}$ and $\mathrm{Mg}^{2+}>\mathrm{Ca}^{2+}>\mathrm{Na}^{+}>\mathrm{K}^{+}$for wet and dry seasons, respectively, while for anions $\mathrm{Cl}^{-}>\mathrm{SO}_{4}{ }^{2-}>\mathrm{HCO}_{3}{ }^{-}>\mathrm{NO}_{3}{ }^{-}$for wet and dry seasons. The order of distribution of the major anions was not affected by seasonal variation, but the concentration of the hydrochemical species varies with season. Nitrate and chloride concentrations were generally high in wet season, which is an indication of anthropogenic influence majorly from poor waste management, sanitation and input from agricultural fertilizer application. Nitrate concentration was low in all the zones except in Onitsha zone in dry season. The mean concentrations of iron were 0.63 and $0.78 \mathrm{mg} / \mathrm{L}$ for wet and dry seasons, respectively. These mean values exceeded the permissible guidelines for drinking water. The concentration of iron was generally higher in Onitsha zone, which may be attributable to the presence of Nsugbe Sandstone facies of the Nanka Sand which is highly ferruginized. The major ions are within the permissible guidelines for drinking water.

\section{Classification of water using hydrochemical facies}

Two major water types, $\mathrm{Ca}-\mathrm{Mg}-\mathrm{HCO}_{3}(17.1 \%)$ and $\mathrm{Na}-\mathrm{K}-\mathrm{Cl}-\mathrm{SO}_{4}(82.9 \%)$, were observed using Morgan 
Table 3 Distributions of the ionic species in water sources in the study area

\begin{tabular}{lll}
\hline Zones & Ionic species in decreasing order & \\
\cline { 2 - 3 } & Wet season & Dry season \\
\hline Onitsha & $\mathrm{K}^{+}>\mathrm{Ca}^{2+}>\mathrm{Mg}^{2+}>\mathrm{Na}^{+}$ & $\mathrm{Mg}^{2+}>\mathrm{Ca}^{2+}>\mathrm{K}^{+}>\mathrm{Na}^{+}$ \\
Obosi/Ojoto & $\mathrm{Cl}^{-}>\mathrm{NO}_{3}{ }^{-}>\mathrm{SO}_{4}{ }^{2-}>\mathrm{HCO}_{3}{ }^{-}$ & $\mathrm{Cl}^{-}>\mathrm{SO}_{4}{ }^{2+}>\mathrm{HCO}_{3}{ }^{-}>\mathrm{NO}_{3}{ }^{-}$ \\
& $\mathrm{K}^{+}>\mathrm{Ca}^{2+}>\mathrm{Na}^{+}>\mathrm{Mg}^{2+}$ & $\mathrm{Mg}^{2+}>\mathrm{Na}^{+}>\mathrm{K}^{+}>\mathrm{Ca}^{2+}$ \\
Nsugbe/Aguleri & $\mathrm{Cl}^{-}>\mathrm{HCO}_{3}{ }^{-}>\mathrm{SO}_{4}{ }^{2-}>\mathrm{NO}_{3}{ }^{-}$ & $\mathrm{SO}_{4}{ }^{2-}>\mathrm{Cl}^{-}>\mathrm{HCO}_{3}{ }^{-}>\mathrm{NO}_{3}{ }^{-}$ \\
& $\mathrm{Na}^{+}>\mathrm{K}^{+}>\mathrm{Ca}^{2+}>\mathrm{Mg}^{2+}$ & $\mathrm{Ca}^{2+}>\mathrm{Na}^{+}>\mathrm{Mg}^{2+}>\mathrm{K}^{+}$ \\
Nkwelle-Ezunaka & $\mathrm{SO}_{4}{ }^{2-}>\mathrm{Cl}^{-}>\mathrm{HCO}_{3}{ }^{-}>\mathrm{NO}_{3}{ }^{-}$ & $\mathrm{HCO}_{3}^{-}>\mathrm{Cl}^{-}>\mathrm{SO}_{4}{ }^{2-}>\mathrm{NO}_{3}{ }^{-}$ \\
& $\mathrm{K}^{+}>\mathrm{Ca}^{2+}>\mathrm{Na}^{+}>\mathrm{Mg}^{2+}$ & $\mathrm{Na}^{+}>\mathrm{Ca}^{2+}>\mathrm{K}^{+}>\mathrm{Mg}^{2+}$ \\
Surface water & $\mathrm{HCO}_{3}{ }^{-}>\mathrm{Cl}^{-}>\mathrm{SO}_{4}{ }^{2-}>\mathrm{NO}_{3}{ }^{-}$ & $\mathrm{HCO}_{3}^{-}>\mathrm{SO}_{4}{ }^{2-}>\mathrm{Cl}^{-}>\mathrm{NO}_{3}{ }^{-}$ \\
& $\mathrm{K}^{+}>\mathrm{Ca}^{2+}>\mathrm{Mg}^{2+}>\mathrm{Na}^{+}$ & $\mathrm{K}^{+}>\mathrm{Ca}^{2+}>\mathrm{Na}^{+}>\mathrm{Mg}^{2+}$ \\
& $\mathrm{SO}_{4}{ }^{2-}>\mathrm{Cl}^{-}>\mathrm{HCO}_{3}{ }^{-}>\mathrm{NO}_{3}{ }^{-}$ & $\mathrm{SO}_{4}{ }^{2-}>\mathrm{Cl}^{-}>\mathrm{HCO}_{3}{ }^{-}>\mathrm{NO}_{3}{ }^{-}$ \\
\hline
\end{tabular}
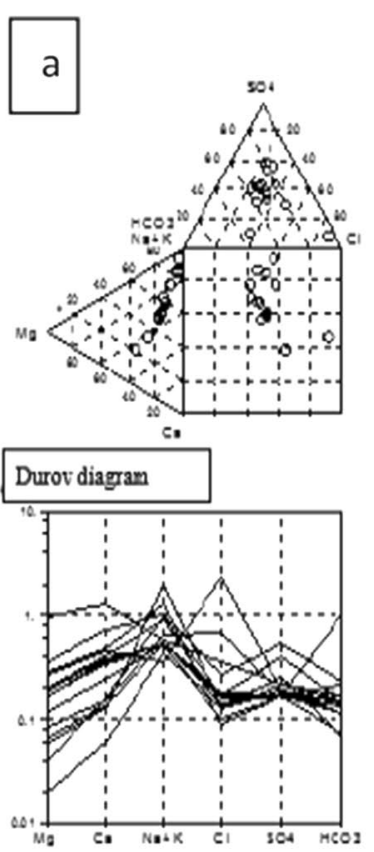

Schoeller diagram

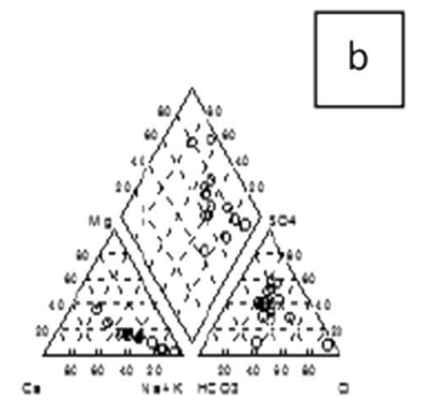

Piper diagram

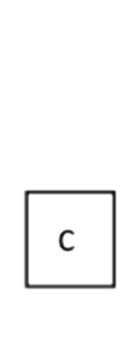

Wet season

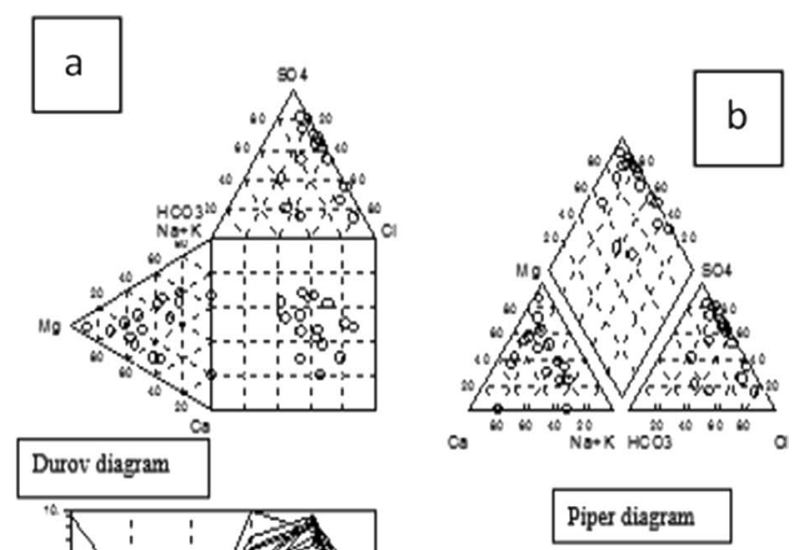

Schoeller diagram

Dry season

Fig. 2 Diagrammatical representation of hydrochemical species a Durov, b Piper and $\mathbf{c}$ Schoeller in Onitsha zone

et al. (1962) and Back and Hanshaw (1965) classifications of the Piper diagram (Fig. 2). In all the zones, the water types were not affected by season. The dominant ions in Onitsha and Obosi zones were $\mathrm{SO}_{4}{ }^{2-}$ and $\mathrm{Na}+\mathrm{K}$ in both seasons, while Aguleri zone recorded no dominant ion in both seasons. However, surface water recorded no dominant ions in wet season, while $\mathrm{SO}_{4}{ }^{2-}$ was dominant in dry seasons. Also Nkwelle zone recorded no dominant ion in dry season, but $\mathrm{Na}+\mathrm{K}$ was dominant in wet season (Figs. 2, 3 and 4). Using Lloyd and Heatcoat (1985) classification, the water sources depict water that has resulted in or from dissolution of the rock along their flow path as well as mixing of water from different sources which was further buttressed by no dominant ions. Weathering of carbonates and silicates was responsible for the presence of $\mathrm{Ca}^{2+}, \mathrm{Mg}^{2+}, \mathrm{HCO}_{3}{ }^{-}$and $\mathrm{SO}_{4}{ }^{2-}$; and $\mathrm{Na}^{+}$and $\mathrm{K}^{+}$ions, respectively.

The presence of various hydrochemical facies confirms the mixing of water from different recharge areas, characterized by different lithologic units. The chemistry of the water is dominated by the alkaline earth metals $\left(\mathrm{Ca}^{2+}\right.$ and $\left.\mathrm{Mg}^{2+}\right)$ and the alkaline metals $(\mathrm{Na}+\mathrm{K})$ and the strong acids 


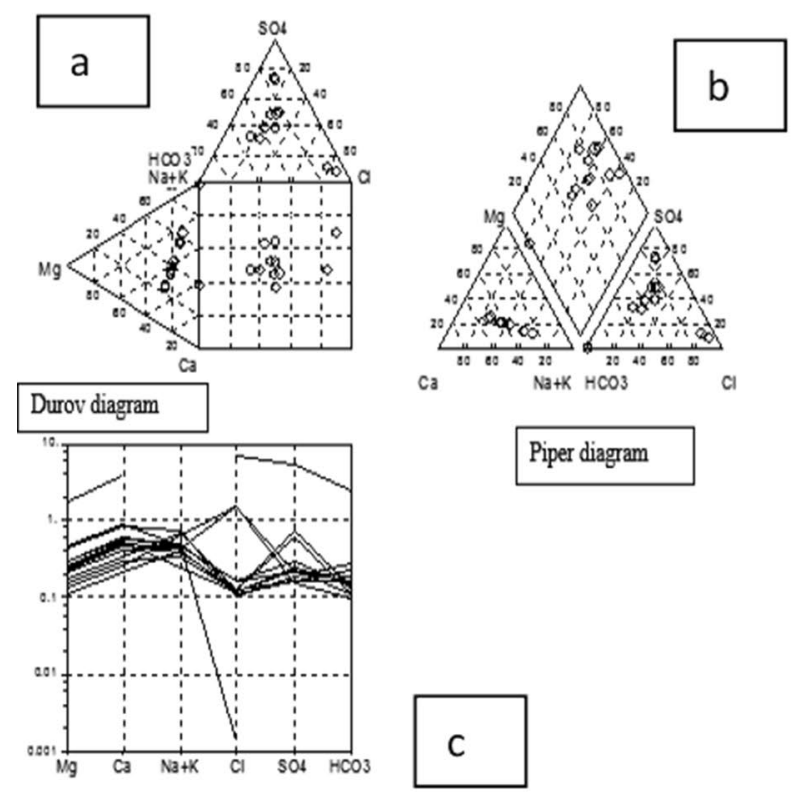

Schoeller diagram
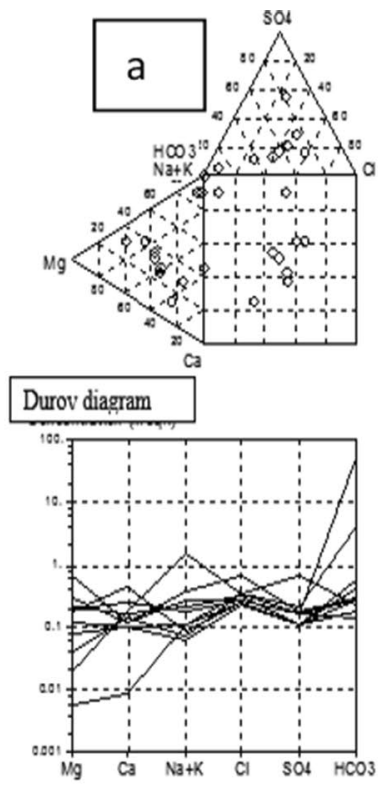

$\mathrm{Ca}$

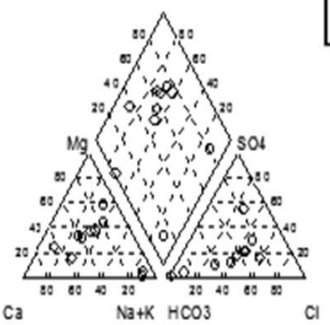

b

\section{Schoeller diagram}

Wet season

\section{Dry season}

Fig. 3 Diagrammatical representation of hydrochemical species a Durov, b Piper and $\mathbf{c}$ Schoeller in Aguleri zone

Fig. 4 Diagrammatical representation of hydrochemical species a Durov, b Piper and c Schoeller in water sources in the study area
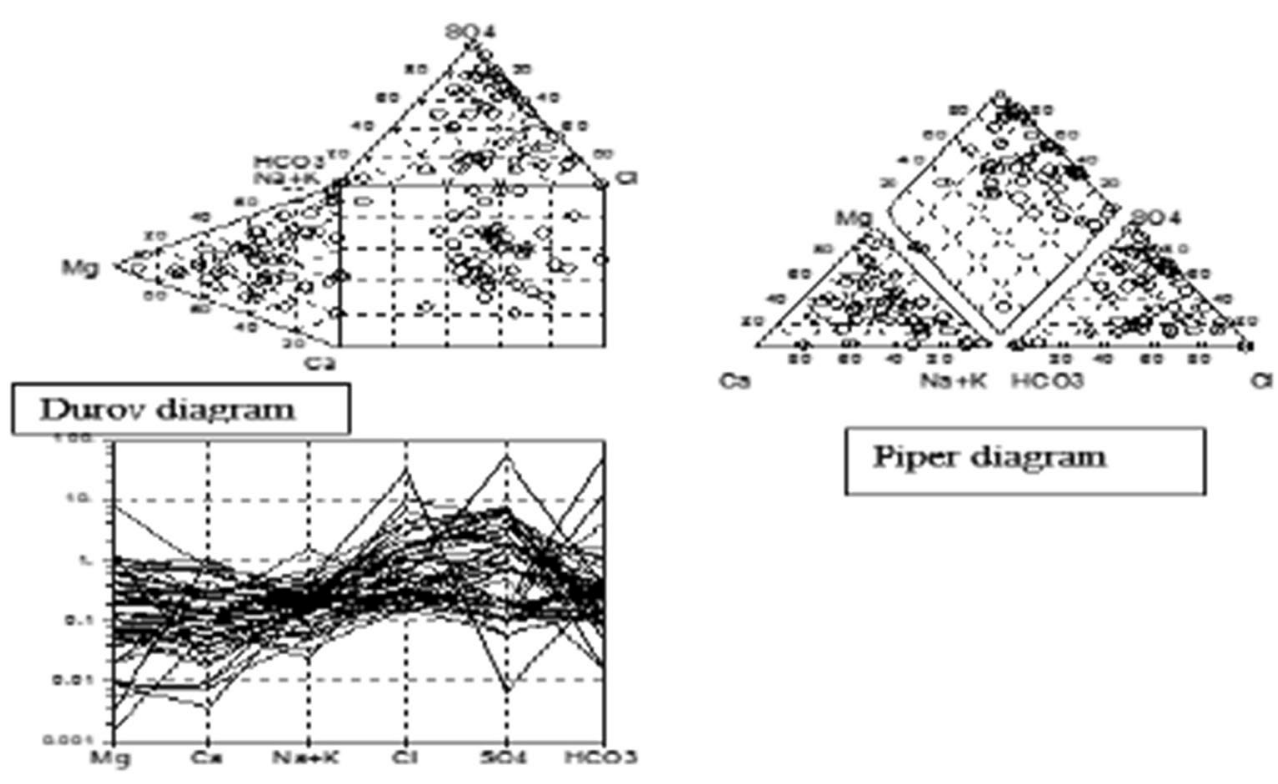

Piper diagram

Schoeller diagram

$\left(\mathrm{Cl}^{-}\right.$and $\left.\mathrm{SO}_{4}{ }^{2-}\right)$. The presence of $\mathrm{SO}_{4}{ }^{2-}$ accompanied by $\mathrm{Ca}^{2+}$ and $\mathrm{Mg}^{2+}$ ions can be attributed to non-marine origin and the presence of calcareous sands; while $\mathrm{Na}^{+}$and $\mathrm{K}^{+}$ions are from feldspar, alluding to the influence of geology. Variation in ionic facies was observed: the dominant facies being; $\mathrm{Cl}^{-}$and $\mathrm{SO}_{4}{ }^{2-}$ types, which include $\mathrm{Na}-\mathrm{Cl}, \mathrm{Ca}-\mathrm{Cl}, \mathrm{Mg}-\mathrm{SO}_{4}-\mathrm{Cl}, \mathrm{Ca}-\mathrm{Mg}-\mathrm{Cl}, \mathrm{Mg}-\mathrm{Na}-\mathrm{Cl}-\mathrm{SO}_{4}$, $\mathrm{Ca}-\mathrm{Cl}-\mathrm{HCO}_{3}-\mathrm{SO}_{4}$ and $\mathrm{Mg}-\mathrm{Ca}-\mathrm{Na}-\mathrm{SO}_{4}$, respectively, and 
Table 4 Summary of result of hydrochemical facies from Durov diagram

\begin{tabular}{ll}
\hline Parameters & Percentage \\
\hline $\mathrm{Mg}^{2+}$ & 18.3 \\
$\mathrm{Ca}^{2+}$ & 10 \\
$\mathrm{Na}+\mathrm{K}$ & 16.7 \\
$\mathrm{No}$ dominant cation & 55 \\
$\mathrm{Cl}^{-}$ & 15 \\
$\mathrm{No} \mathrm{dominant} \mathrm{anion}^{2+}$ & 13.3 \\
$\mathrm{SO}_{4}{ }^{2-}$ & 71.7 \\
$\mathrm{No}^{2}$ dominant anion or cation & Water that has undergone \\
& mixing and simple dissolu- \\
Water related to reverse ion exchange & tion (67.7) \\
\hline
\end{tabular}

lesser amount of $\mathrm{HCO}_{3}$ facies which include $\mathrm{Ca}-\mathrm{SO}_{4}-\mathrm{HCO}_{3}$, $\mathrm{Na}-\mathrm{Ca}-\mathrm{Mg}-\mathrm{HCO}_{3}$ and $\mathrm{Ca}-\mathrm{Mg}-\mathrm{HCO}_{3}$. The variation in facies indicates mixing of water from different sources, while ion exchange processes led to an increased concentration of $\mathrm{Ca}^{2+}$ and $\mathrm{Mg}^{2+}$ in relation to $\mathrm{Na}^{+}$. Thus interpretation of Piper diagram using Back and Hanshaw (1965) classification showed that the alkali earths exceed alkaline metal $(\mathrm{Na})$; and $22.5 \%$ of sampled water exhibit mixed type with no dominant cation pair exceeding $50 \%$. Therefore, the hydrochemistry is dominated by $\mathrm{Ca}+\mathrm{Mg}$ and $\mathrm{SO}_{4}+\mathrm{Cl}$ facies. $\mathrm{Ca}-\mathrm{Cl}$ and $\mathrm{SO}_{4}{ }^{2-}$ as dominant facies indicate the existence of inverse ion exchange (Table 4), and these facies types are peculiar to water found in discharge areas.

\section{Conclusion}

$\mathrm{Ca}-\mathrm{Mg}-\mathrm{HCO}_{3}$ and $\mathrm{Na}-\mathrm{K}-\mathrm{Cl}-\mathrm{SO}_{4}$ water types were observed. The water types were not affected by season. The distribution of the ionic species varied with season and location. This variation may be attributed to geochemical processes and rock-water interaction. The dominant anion is $\mathrm{SO}_{4}{ }^{2-}$, while cation is $\mathrm{Na}+\mathrm{K}$. The absence of dominant ion in some zones and the presence of various ionic facies denote mixing of water from different sources, characterized by different lithologic units. Ion exchange processes have resulted in increased concentration of $\mathrm{Ca}^{2+}$ and $\mathrm{Mg}^{2+}$ in relation to $\mathrm{Na}^{+}$; hence, the hydrochemistry is dominated by $\mathrm{Ca}+\mathrm{Mg}$ and $\mathrm{SO}_{4}+\mathrm{Cl}$ facies.

Open Access This article is distributed under the terms of the Creative Commons Attribution 4.0 International License (http://creativeco mmons.org/licenses/by/4.0/), which permits unrestricted use, distribution, and reproduction in any medium, provided you give appropriate credit to the original author(s) and the source, provide a link to the Creative Commons license, and indicate if changes were made.

\section{References}

Aghazadel N, Chitsazan M, Golestan Y (2016) Hydrogeochemistry and quality assessment of groundwater in Arabil area, Iran. https ://doi.org/10.1007/S13201-0160498-9

American Public Health Association (APHA) (1998) Standard method for the examination of water and wastewater, 20th edn. APHA, Washington, pp 9-132

Back W, Hanshaw L (1965) Chemical geohydrology; advances in hydrosciences. Academic Press, New Jersey, pp 49-109

Barzegar RA, Moghaddam A, Najib M, Adamowski J (2016) Characterisation of hydrogeologic properties of the Tabriz Plain multi-aquifer system, Northwest Iran. Arab J Geosci. https://doi. org/10.1007/S12517-015-229-1

Batayneh A, Zaman H, Zumlot T, Ghrefat A, Nazzal Y, Elawadi E, Qaisy S, Bahkey I, Al-Taani A (2014) Hydrochemical facies and ionic ratios of the coastal groundwater aquifer of Saudi Gulf of Aqaba: implications for seawater. J Res 30(1):75-87

Bonoto DM (2006) Hydro (radio) chemical relationships in giant Guarani aquifer. Braz J Hydrogeol 323:353-386

Edet AE, Nganje TN, Ukpong AJ, Ekwere AS (2011) Groundwater chemistry and quality of Nigeria: a status review. Afr J Environ Sci Technol 5(13):1152-1169

Elango L, Suresh Kumar S, Rajmohan N (2003) Hydrochemical studies of groundwater in Chengalpet region, south India. Indian J Environ Prot 23(6):624-632

Ige OO, Karade IA (2014) Effects of seasonal variation on groundwater facies classification in Otte, southwestern Nigeria. Ilorin J Sci $1(1): 61-73$

Jalali M (2008) Major ion chemistry of groundwater in the Bahar Area, Hamadan western Iran. Environ Geol 47:763-772

Lakshamanan E, Kannan R, Kumar MS (2003) Major ion chemistry and identification of hydrochemical processes of groundwater in a part of Kancheepuram District, Tamil Nadu, India. Environ Geosci 10(4):157-166

Lloyd JW, Heatcoat JA (1985) National inorganic chemistry in relation to groundwater. Calderon Press, Oxford, pp 114-145

Morgan CO, Winner MD (1962) Hydrochemical facies in the 400 foot and 600 foot sands of the Baton Rouge area, Louisiana. US Geol Surv Prof Paper 450:120-121

Nigerian Standard for Drinking Water Quality (NSDWQ) (2007) Nigerian Industrial Standard (NIS) 554, Standard Organization of Nigeria: 30

Nwankwoala HO (2013) Aquifer hydraulic conductivity determination from grain size analysis in parts of old Port-Harcourt Township, Nigeria. ARPN J Sci Technol 3(9):972-981

Nwankwoala HO, Udom GJ (2011) Hydrogeochemical evaluation of groundwater in parts of Eastern Niger Delta, Nigeria. J Acad Appl Stud 1(2):33-58

Ravnborg HM (2016) Water governance reform in the context of inequality; security rights or legitimizing dispossession? Water Int 41(6):920-943

World Health Organization (2008) Guidelines for drinking water quality, 3rd edn. 3 Recommendations, Geneva, pp 303-322

Wurbs RA (2017) Incorporation of environmental flows in water allocation in Texas. Water Int 42(1):18-23

Publisher's Note Springer Nature remains neutral with regard to jurisdictional claims in published maps and institutional affiliations. 